\title{
IS IT TIME TO REDEFINE COGNITIVE DYSFUNCTION AFTER CARDIAC SURGERY? THE IMPORTANCE OF METHODOLOGICAL CONSISTENCY
}

\author{
Sandro Glumac ${ }^{1}$, Goran Kardum ${ }^{2}$ and Nenad Karanović ${ }^{1,3}$ \\ ${ }^{1}$ Department of Anesthesiology and Intensive Care, Split University Hospital Centre, Split, Croatia; \\ ${ }^{2}$ Department of Psychology, Faculty of Humanities and Social Sciences, University of Split, Split, Croatia; \\ ${ }^{3}$ Department of Anesthesiology and Intensive Medicine, School of Medicine, University of Split, Split, Croatia
}

\begin{abstract}
SUMMARY - High incidence and significance of repercussions on patient health and healthcare system make postoperative cognitive dysfunction (POCD) a major problem following cardiac surgery. POCD frequency drops over time since surgery and its occurrence are related to different aspects of cognitive deterioration that markedly impair the patient quality of life. Therefore, a substantial number of papers have focused on this complex postoperative complication, however, with limited achievement in clarifying it. The underlying mechanisms of POCD development and contributing factors are still unclear. A significant issue in POCD research is the lack of uniformity in defining cognitive impairment among investigators, including unique terminology of cognitive changes, a battery of appropriate neuropsychological tests, timing of assessment, and statistical approach. Thus, the aim of this review is to address the difficulties in establishing POCD definition, with inclusion of specific recommendations based on recent publications.
\end{abstract}

Key words: Cardiac surgical procedures; Cardiopulmonary bypass; Cognition disorders; Cognitive dysfunction; Neuropsychological tests; Postoperative complications

\section{Introduction}

Postoperative cognitive dysfunction (POCD) following cardiac surgery represents a major concern for anesthesiologists. Aside from association with markedly adverse outcomes during early postoperative period, including increased mortality, the appearance of POCD is also related to various long-term outcomes such as reduced quality of life, work inability, and early retirement, which significantly increase healthcare costs $^{1,2}$. In the early 1970 s, first reports on mild postoperative cognitive deficits were linked to introducing cardiopulmonary bypass in common practice of cardi-

Correspondence to: Sandro Glumac, $M D, P h D$, Department of Anesthesiology and Intensive Care, Split University Hospital Centre, Spinčićeva 1, HR-21000 Split, Croatia

E-mail: sandro.glumac@gmail.com

Received November 7, 2019, accepted February 4, 2020 ac surgical procedures ${ }^{3}$. However, decades later, several issues regarding this phenomenon are still unclear ${ }^{4}$. In particular, the pathogenesis of POCD is poorly understood, and their incidence is consistent over years, becoming the most frequent postoperative complication after cardiac surgery ${ }^{1}$. The role of inflammatory response to surgical procedures has recently turned into a promising direction in the investigation of POCD development ${ }^{2}$. Also, substantial evidence suggests significant involvement of cerebral microemboli, cerebral autoregulation dysfunction, cerebral hypoperfusion, as well as anesthesia- and patient-related risk factors in POCD occurrence ${ }^{3,5,6}$. Recent studies have emphasized the importance of preserving cerebral blood flow by introducing an intervention algorithm in case of intraoperative cerebral oxygen desaturation ${ }^{3,7}$. It seems that surgery perfusion- and patient-related risk factors are more related with POCD development than anes- 
thesia-related risk factors, although certain anesthetics have more favorable effects on cognitive functions ${ }^{8}$. Dexmedetomidine, as well as ketamine administration during anesthesia induction decreased the incidence of POCD, most likely through their anti-inflammatory activity ${ }^{9,10}$. Despite expectations from a newer surgical technique, i.e., beating-heart surgery, beneficial effects on cognition have not been reported ${ }^{3,6}$. Nevertheless, certain techniques such as 'no-touch' approach, ultrafiltration- and leukocyte-depletion methods, minimized extracorporeal circulation, and cell saver devices produced more promising results ${ }^{3}$.

Notably, POCD studies reflect methodological confusion in defining cognitive impairment ${ }^{3,11,12}$. Therefore, the purpose of this review is to point to the significance of methodological issues in conducting POCD studies by identifying relevant obstacles and providing suggestions for future research.

\section{Methodological Inconsistency}

A simple search of the PubMed database using two medical subject heading $(\mathrm{MeSH})$ terms, i.e., cardiac surgical procedures and cognitive dysfunction, revealed 410 related publications, indicating the high level of attention that different experts have dedicated to this interesting topic. Perhaps the most valid reason why the expected breakthrough in clarifying this clinically important query has been lacking over time lies in inconsistent methodology that has been used in POCD studies $^{3,13}$. Therefore, similarly designed studies very often provide contradictory results, significantly complicated conclusions, and fail to set proper directions for future research ${ }^{12}$.

It is important to note that in 1994, a task force of multidisciplinary experts was assembled in Fort Lauderdale, Florida, USA, to set order in the methodology mixture that has been employed among POCD investigators ${ }^{14}$. However, the conference yielded only partial success, as the recommended guidelines were not strictly adopted among POCD researchers ${ }^{3}$. Nevertheless, several novel issues have emerged since that meeting.

\section{Discussion}

Selection of convenient nomenclature for cognitive deterioration, neuropsychological test battery, assessment timing, and statistical method constitute signifi- cant obstacles POCD investigators must face ${ }^{3,6,12}$.Also, because of the high prevalence of depression and anxiety in the population, investigators must exclude their implications on the neuropsychological test results ${ }^{8}$.

In 2018, a multispecialty working group led by Evered published recommendations stating that terminology which is being used in cognitive classifications of general population should also be applied in the investigations of cognitive changes after surgical procedures. Their goal is to shift POCD research from isolation, reserved specifically for anesthesiologists and this narrow field of expertise, into a broader and visibly clinical area ${ }^{15}$. Hence, if we achieve unique diagnostic criteria to be used in POCD studies and in general population of patients with neurocognitive disorders, it should enhance the quality of research and consistency of scientific communication among POCD investigators.

Another issue is that our search of the PubMed database disclosed over 100 different neuropsychological tests used in published studies for establishing POCD diagnosis. Significantly, test battery must be unvarying, and it must consist of a minimal number of tests to avoid exhaustion of patients, while showing adequate sensitivity and specificity to detect cognitive changes of different domains that cardiac surgical procedure may affect ${ }^{3,6,11}$.

The selection of appropriate perioperative times for the administration of neuropsychological tests to patients is also a very slippery road ${ }^{3}$. Preoperative evaluation is mandatory, and most likely the best time to carry out testing is between seven to ten days before surgical procedure to avoid anxiety impact of upcoming surgery on test results. On the other hand, early postoperative assessment should be at the earliest seven days following surgery to reduce the effect of surgical pain, pharmacological interventions and sleep deprivation on test findings ${ }^{12}$. Furthermore, as early postoperative period may be complicated by development of delirium, to avoid misleading diagnosis, and bearing in mind that delirium is a well-recognized predictor of POCD occurrence, neuropsychological testing must be accompanied with delirium assessment, and its appearance must be documented ${ }^{8,16}$. In addition, later postoperative cognitive evaluation most likely should be performed at three months after cardiac surgery, when full physical, neurophysiological, and emotional recovery from exhausting surgical procedure is expect- 
$\mathrm{ed}^{5}$. Moreover, as a result of extensive nature of POCD development, and to track earlier diagnosed cognitive impairment, another late cognitive evaluation is obligatory, likely at twelve months following surgery ${ }^{11,12}$. However, late cognitive assessments are particularly questionable, given that late cognitive deterioration may be just repercussion of the progression of cardiovascular or cerebrovascular diseases, natural aging, or dementia ${ }^{13}$.

At last, different statistical methods have been commonly utilized to define POCD, however, each representing a two-sided coin ${ }^{12}$. A reliable change index seems to be most suitable for POCD research, as it overcomes learning effect, however, this method advocates the inclusion of a control group, which can be very tricky ${ }^{13}$. Specifically, the absence of physiological processes induced by cardiopulmonary bypass and cardiac surgery itself in patients included in a control group represents a significant bias that cannot be overpowered. Our two previous papers addressed the significance of determined statistical threshold and minimal number of tests required to show decline in the reported POCD incidence, which is an area of great variability among published studies ${ }^{1,12}$. Firstly, when we applied strict criteria, i.e., using a difference of 2 standard deviations from the baseline scores as a definition of cognitive impairment instead of liberal definition, i.e., 1 standard deviation, POCD incidence dropped from $66.7 \%$ to $25.9 \%$ of patients in our sample $^{12}$. Subsequently, the use of at least 2 declined tests, compared to 1 declined test, needed to establish POCD diagnosis, decreased the POCD incidence in our patient sample from $55 \%$ to $19.2 \%{ }^{1}$.

\section{Future Directions}

The latest findings suggest that clinicians should focus their efforts on the modifiable contributing factors for POCD development ${ }^{8}$, such as cardiovascular and cerebrovascular optimization of patients by selecting modern perioperative strategy that consists of preoperative corticosteroid administration to attenuate the inflammatory response ${ }^{2,17}$, maintaining mean arterial pressure between 80 and $90 \mathrm{~mm} \mathrm{Hg}$ during cardiopulmonary bypass without marked intraoperative pressure dropping in order to preserve cerebral autoregulation ${ }^{3}$, and by performing manipulations that enhance intraoperative cerebral oxygen saturation ${ }^{7}$.
However, numerous authors take excessive liberty in defining cognitive deterioration after cardiac surgery, which directs POCD research into a dead end. Thus, it is essential to set solid criteria in defining cognitive impairment following cardiac surgery by carrying out a new consensus from the leading authorities in this growing field of perioperative medicine. The best model to complete this task is to organize a new annual conference of renowned researchers to discuss the current knowledge and to update the current guidelines if necessary. This approach will enable the investigators and readers to better understand the study findings and more easily compare results of similar studies, while ensuring that genuine study results have been clearly reported and broadly disseminated.

\section{References}

1. Glumac S, Kardum G, Karanovic N. A prospective cohort evaluation of the cortisol response to cardiac surgery with occurrence of early postoperative cognitive decline. Med Sci Monit. 2018;24:977-86. doi: 10.12659/msm.908251

2. Glumac S, Kardum G, Sodic L, Supe-Domic D, Karanovic N. Effects of dexamethasone on early cognitive decline after cardiac surgery: a randomised controlled trial. Eur J Anaesthesiol. 2017;34:776-84. doi: 10.1097/EJA.0000000000000647

3. Glumac S, Kardum G, Karanovic N. Postoperative cognitive decline after cardiac surgery: a narrative review of current knowledge in 2019. Med Sci Monit. 2019;25:3262-70. doi: 10.12659/MSM.914435

4. Smith PJ, Browndyke JN, Monge ZA, et al. Longitudinal changes in regional cerebral perfusion and cognition after cardiac operation. Ann Thorac Surg. 2019;107:112-8. doi: 10.1016/j.athoracsur.2018.07.056

5. Vedel AG, Holmgaard F, Siersma V, et al. Domain-specific cognitive dysfunction after cardiac surgery. A secondary analysis of a randomized trial. Acta Anaesthesiol Scand. 2019; 63:730-8. doi: 10.1111/aas.13343

6. Yuan SM, Lin H. Postoperative cognitive dysfunction after coronary artery bypass grafting. Braz J Cardiovasc Surg. 2019; 34:76-84. doi: 10.21470/1678-9741-2018-0165

7. Deschamps A, Hall R, Grocott $\mathrm{H}$, et al. Cerebral oximetry monitoring to maintain normal cerebral oxygen saturation during high-risk cardiac surgery: a randomized controlled feasibility trial. Anesthesiology. 2016;124:826-36. doi: 10.1097/ ALN.0000000000001029

8. Ntalouka MP, Arnaoutoglou E, Tzimas P. Postoperative cognitive disorders: an update. Hippokratia. 2018;22:147-54.

9. Rajaei M, Tabari M, Soltani G, et al. Comparison between the effects of dexmedetomidine and midazolam on postoperative cognitive impairment after coronary artery bypass graft sur- 
gery: a randomized clinical trial. J Tehran Heart Cent. 2019; 14:67-73.

10. Hudetz JA, Iqbal Z, Gandhi SD, et al. Ketamine attenuates post-operative cognitive dysfunction after cardiac surgery. Acta Anaesthesiol Scand. 2009;53:864-72. doi: 10.1111/j.13996576.2009.01978.x

11. Pacic-Turk L, Jandrijevic P, Havelka-Mestrovic A. Recovery of memory after cerebral artery aneurysm surgery. Acta Clin Croat. 2019;58:229-39. doi: 10.20471/acc.2019.58.02.05

12. Glumac S, Kardum G, Karanovic N. Reply to: Dexamethasone and postoperative cognitive decline. Eur J Anaesthesiol. 2018; 35:635-6. doi: 10.1097/EJA.0000000000000843

13. Giovannetti T, Price CC, Fanning M, et al. Cognition and cerebral infarction in older adults after surgical aortic valve replacement. Ann Thorac Surg. 2019;107:787-94. doi: 10.1016 /j.athoracsur.2018.09.057
14. Murkin JM, Newman SP, Stump DA, Blumenthal JA. Statement of consensus on assessment of neurobehavioral outcomes after cardiac surgery. Ann Thorac Surg. 1995;59:1289-95. doi: 10.1016/0003-4975(95)00106-u

15. Evered L, Silbert B, Knopman DS, et al. Recommendations for the nomenclature of cognitive change associated with anaesthesia and surgery-2018. Br J Anaesth. 2018;121:1005-12. doi: 10.1016/j.bja.2017.11.087

16. Stubljar D, Stefin M, Tacar MP, Cerovic O, Grosek S. Prolonged hospitalization is a risk factor for delirium onset: oneday prevalence study in Slovenian intensive care units. Acta Clin Croat. 2019;58:265-73. doi: 10.20471/acc.2019.58.02.09

17. Sakic L, Tonkovic D, Sakic K. Dexamethasone - intrathecal minimiser of simple haemathologic stress biomarkers in hip fracture. Acta Clin Croat. 2019;58:9-17. doi: 10.20471/acc. 2019.58.s1.01

Sažetak

\section{JE LI MOŽDA TRENUTAK DA PREISPITAMO DEFINICIJU KOGNITIVNIH POREMEĆAJA NAKON KARDIOKIRURŠKOG ZAHVATA? VAŽNOST METODOLOŠKE DOSLJEDNOSTI}

\section{S. Glumac, G. Kardum i N. Karanović}

Visoka učestalost i značajnost utjecaja na zdravlje bolesnika i zdravstveni sustav čini poslijeoperacijske kognitivne poremećaje (POKP) važnom komplikacijom kardiokirurškog zahvata. Učestalost POKP nakon zahvata s vremenom se smanjuje te je njihova pojava povezana s različitim poremećajima kognitivnih funkcija, što posljedično značajno narušava kvalitetu bolesnikova života. Stoga, brojni radovi su posvećeni ovoj složenoj poslijeoperacijskoj komplikaciji, ali bez značajnije postignutog uspjeha u njenom razjašnjavanju. Mehanizmi nastanka kao i čimbenici rizika POKP još uvijek su nejasni. Značajnu poteškoću u ispitivanju POKP predstavlja nepostojanje jedinstvene definicije kognitivnog oštećenja među istraživačima, a koje bi zahtijevalo primjenu jedinstvene terminologije kognitivnih promjena, uporabu odgovarajuće baterije neuropsihologijskih testova, odgovarajuće vremenske trenutke provođenja testova i uporabu prikladne statističke metode. Zbog toga, cilj ovog preglednog članka je naglasiti poteškoće s kojim se istraživači susreću tijekom postavljanja dijagnoze POKP, te uključivanje preporuka na temelju pregleda dostupne literature.

Ključne riječi: Kardiokirurški zabvati; Izvantjelesni krvotok; Kognitivni poremé́aji; Kognitivna disfunkcija; Neuropsibologijski testovi; Poslijeoperacijske komplikacije 